\title{
Sustainable Manganese Catalyzed Solvent-Free Synthesis of Pyrroles from 1,4-Diols and Primary Amines
}

\author{
Jannik C. Borghs, ${ }^{\dagger}$ Yury Lebedev, ${ }^{\dagger}$ Magnus Rueping, ${ }^{\dagger *}$ and Osama El-Sepelgy ${ }^{\dagger *}$ \\ 'Institute of Organic Chemistry, RWTH Aachen University, Landoltweg 1, 52074 Aachen, Germany \\ ${ }^{*}$ KAUST Catalysis Center (KCC), King Abdullah University of Science and Technology (KAUST), Thuwal 23955-6900, \\ Saudi Arabia
}

ABSTRACT: A general and selective metal-catalyzed conversion of biomass-derived primary diols and amines to the highly valu-
able 2,5-unsubstituted pyrroles has been developed. The reaction is catalyzed by a stable non-precious manganese complex (1
mol \%) in the absence of organic solvents whereby water and molecular hydrogen are the only side-products. The manganese cata-
lyst developed shows unprecedented selectivity, avoiding the formation of pyrrolidines, cyclic imides and lactones.

The discovery of new sustainable catalytic systems for upgrading renewable feedstocks to value-added fine and bulk chemicals represents central challenge for chemists. ${ }^{1}$ In this context, lignocellulosic biomass derived alcohols offer a green alternative to mutagenic alkyl halides. Thus, substantial work was dedicated to the metal catalyzed activation of alcohols by hydrogen shuttling with transfer of hydrogen from the alcohol to the final product. Besides, the catalytic dehydrogenation of alcohols leads to in situ formation of carbonyl intermediates which can undergo coupling reactions via condensation cascades to give more complex target molecules. ${ }^{2}$

Pyrroles represent an important class of synthetic intermediates which have found numerous applications in medicinal and advanced materials chemistry. ${ }^{3}$ While 2,5-substituted pyrroles are conventionally prepared through the Paal-Knorr synthesis, ${ }^{4}$ approaches for the synthesis of $N$-substituted pyrroles, and in particular 2,5-unsubstituted pyrroles include the Clauson-Kaas reaction $^{5}$ as well as $N$-alkylation of pyrrole. However, these methods may suffer from the formation of stoichiometric amounts of waste and limited substrate scope. More modern methods relay on the ruthenium or iron catalyzed condensation of the more expensive 2-butyne-1,4-diol with primary amines to give $N$-substituted pyrroles. ${ }^{6}$ Recently, a chemoenzymatic synthesis of $N$-substituted pyrrole was achieved via olefin metathesis-aromatization cascade. ${ }^{7}$

A selective catalytic synthesis of $N$-substituted pyrroles from the readily available 1,4-butanediol (1) would be an ideal alternative, producing water and hydrogen gas as the only side products. However, the reaction of diol $\mathbf{1}$ with primary amines often leads to a mixture of pyrrolidine, cyclic imide, pyrrole and lactone (Scheme 1). ${ }^{8}$ Saturated pyrrolidine can be accessed from the primary diol $\mathbf{1}$ and amines using iridium, ruthenium and iron catalysts. ${ }^{6 a, 9}$ Furthermore, Hong el al. reported the selective synthesis of cyclic imides using PNNH$\mathrm{Ru}$ catalyst, whereas a base metal catalyzed version was recently reported by Milstein using PNNH-Mn complex. ${ }^{10}$ Moreover, the cyclization of 1,4-dialdehyde to $\gamma$-butyrolactone was outlined using ruthenium bis-phosphine diamine catalyst. ${ }^{11}$ In contrast, a general catalytic system to access pyrroles from diol 1 and primary amines has not been reported so far, although it could provide a desirable green and sustainable synthesis. $^{12}$

Scheme 1. Metal Catalyzed Coupling of Primary Diols and Primary Amines.

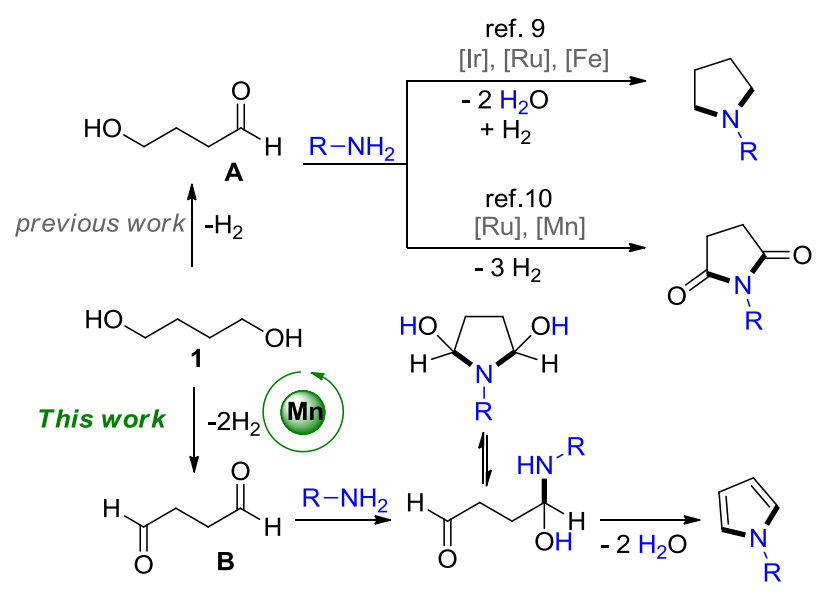

Manganese is the third most abundant transition metal in the earth crust and recently recognized by several groups including ours as a sustainable alternative for $\mathrm{Ru}$ and Ir (de)hydrogenation catalysis. ${ }^{13-17}$ Indeed several catalytic systems have been developed for the hydrogenation of polar and non-polar bonds,$^{15}$ dehydrogenation reactions ${ }^{16}$ and hydrogen autotransfer. ${ }^{17}$ Encouraged by these advances and our experience in metal-ligand cooperative catalysis, ${ }^{18,19}$ we envisioned the possibility of developing a new catalytic system for the efficient in situ generation of the dialdehyde $\mathbf{B}$ from the diol $\mathbf{1}$. This reactive intermediate $\mathbf{B}$ would likely undergo condensation with a primary amine to afford the corresponding pyrrole upon dehydration of the cyclic hemiaminal intermediate. Whereas, the pyrrolidine and imide synthesis typically involves the reaction between the primary amine and the hydroxyaldehyde intermediate $\mathbf{A} .^{9,10}$

Here, we report our results on the sustainable transformation of the readily available diols and primary amines to pyrroles in a highly chemoselective fashion using an earth abundant metal complex based on the inexpensive base metal manganese. We started our study by the preparation of different manganese 
complexes bearing air and moisture stable ligands (Mn-1 Mn-3). For example, the manganese complex Mn-3 could be readily prepared from the commercially available "MACHO" PNP pincer ligand and the inexpensive manganese precursor, $\mathrm{Mn}(\mathrm{CO})_{5} \mathrm{Br}$. Suitable crystals of $\mathbf{M n - 3}$ were obtained and characterized by X-ray diffraction (Figure 1).

Figure 1. Manganese complexes used in this study and the single crystal X-ray structure of $\mathrm{Mn}-3$ with ellipsoid set at $\mathbf{5 0 \%}$ probability level.

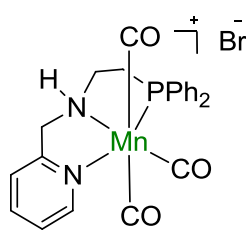

Mn-1

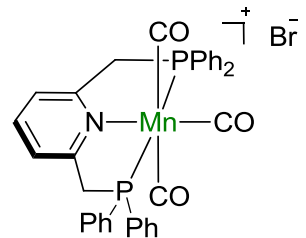

Mn-2

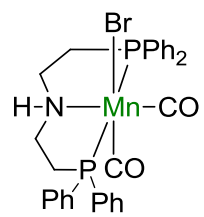

Mn-3

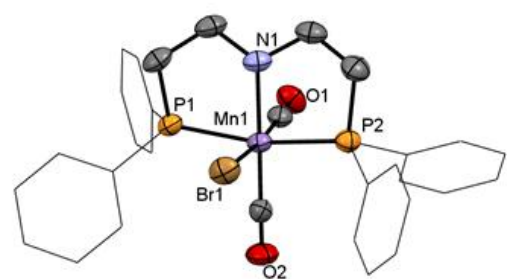

Table 1. Optimization of the Reaction Conditions. ${ }^{a}$

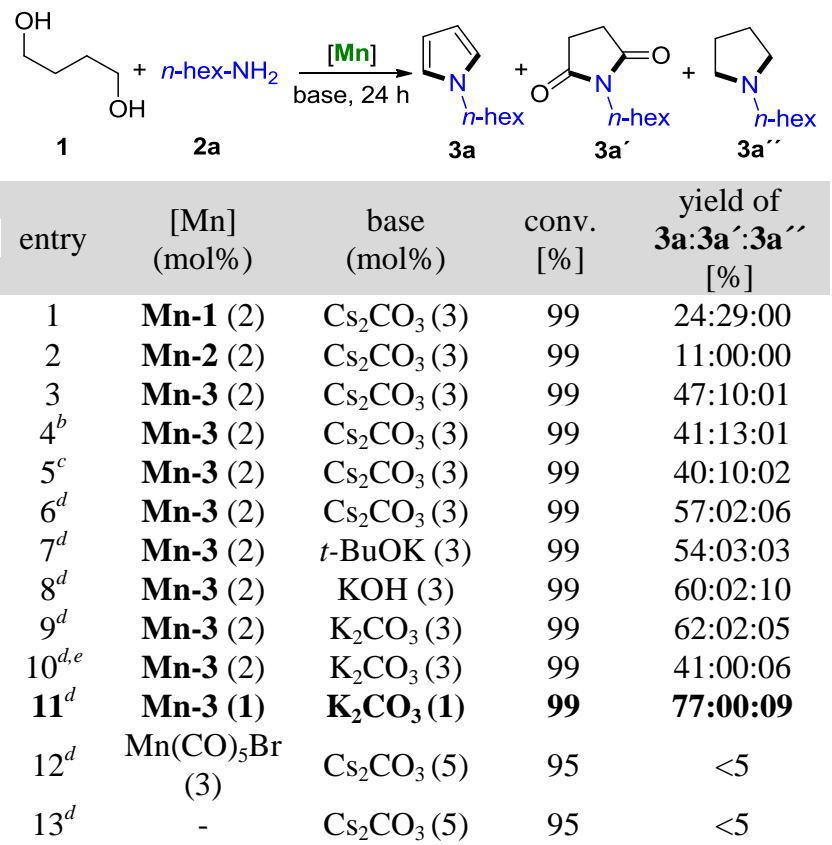

${ }^{a}$ Reaction conditions: $1(0.5 \mathrm{mmol}), 2(1.0 \mathrm{mmol})$ in dioxane $(1.0 \mathrm{M})$ at $150{ }^{\circ} \mathrm{C}$ for $24 \mathrm{~h}$ under argon atmosphere. Conversions and yields were determined by GC using mesitylene $(0.2$ $\mathrm{mmol})$ as an internal standard. ${ }^{b}$ reaction in toluene ${ }^{c}$ reaction in CPME. ${ }^{d}$ neat condition. ${ }^{e} 4 \AA$ mol sieves added. It is worth to note that the difference between yields and conversion is attributed to the formation of oligomeric side products that cannot be detected by GC-analysis.

Subsequently, the reaction between 1,4-butanediol (1) and nhexylamine (2a) was thoroughly investigated in order to find the appropriate reaction conditions for the synthesis of the desired pyrrole 3a while suppressing the formation of the undesired side products 3a' and 3a'" (Table 1). To evaluate the most efficient catalyst, the manganese complexes Mn-1 Mn-3 were tested in combination with $\mathrm{Cs}_{2} \mathrm{CO}_{3}$ in dioxane as a solvent. Indeed, the application of Mn-1 having a PNN ligand led to full conversion with $24 \%$ of the desired pyrrole $\mathbf{3 a}$ along with $29 \%$ of the imide $\mathbf{3 a}$ ' (Table 1, entry 1). The high yield of the imide may be explained by the presence of the hemi-labile pyridine ligand. In contrast, the pyridyl-based PNP pincer complex Mn-2 showed low reactivity and excellent chemoselectivity towards the formation of the desired pyrrole 3a. To our delight, Mn-3 bearing a backbone N-H group resulted in $47 \%$ yield of pyrrole $\mathbf{3 a}$ and $10 \%$ of cyclic imide $\mathbf{3 a}$ ", (Table 1, entry 3 ). We then turned our attention towards fine tuning of the catalytic system by investigating different solvents and bases.

Scheme 2. Manganese Catalyzed Coupling of Primary Amines with 1,4-Butanediol. ${ }^{a}$

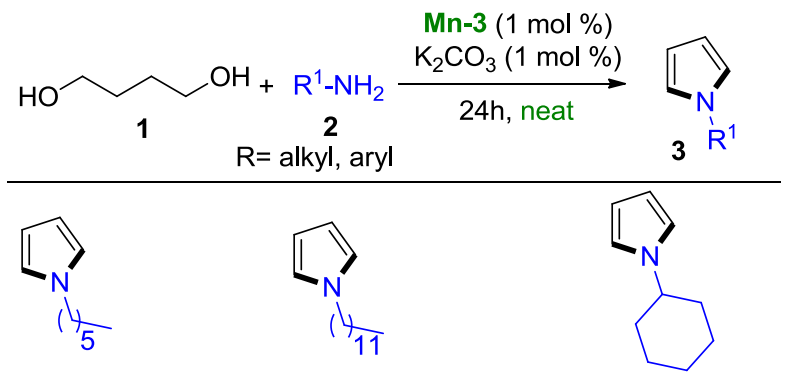

3a, $73 \%$

3b, $75 \%$
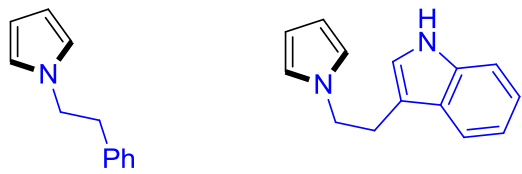

3c, $68 \%$

$3 d, 83 \%$

$3 \mathbf{e}, 78 \%$
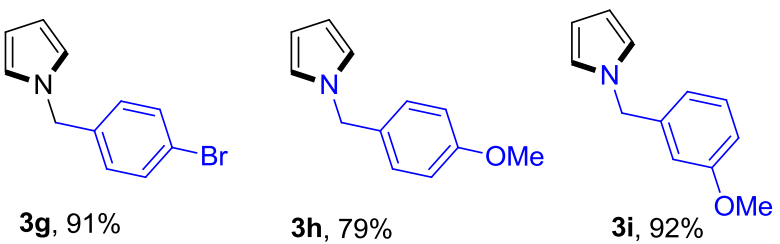

$3 g, 91 \%$

3 h, $79 \%$

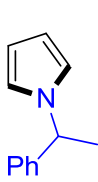

$3 \mathbf{j}, 81 \%$<smiles>c1ccc(C(c2ccccc2)n2cccc2)cc1</smiles>

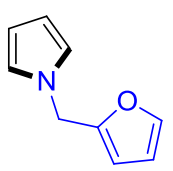

$3 \mathbf{k}, 61 \%$

3I, $76 \%$<smiles>[PbH2]n1cccc1</smiles>

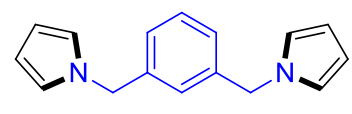

$3 m, 53 \%$

$3 n, 42 \%$

3o, $62 \%^{b}$

${ }^{a}$ Reaction conditions: 1 (0.5 mmol), 2 (1.0 mmol), Mn-3 (0.005 $\mathrm{mmol}), \mathrm{K}_{2} \mathrm{CO}_{3}(0.005 \mathrm{mmol})$ at $150{ }^{\circ} \mathrm{C}$ for $24 \mathrm{~h} .{ }^{b}$ diamine $(0.5$ $\mathrm{mmol}), \mathbf{1}(1.5 \mathrm{mmol})$.

When dioxane was replaced by toluene or CPME, both yield and selectivity slightly decreased (Table 1, entries 4-5). Surprisingly, running the reaction under neat condition led to improved reactivity and selectivity (Table 1, entry 6). The 
influence of different bases, such as $t$-BuOK, $\mathrm{KOH}, \mathrm{K}_{2} \mathrm{CO}_{3}$, was also examined (Table 1, entries 7-9). We found that the inexpensive $\mathrm{K}_{2} \mathrm{CO}_{3}$ could be used as a catalyst activator providing $62 \%$ of pyrrole $\mathbf{3 a}$ and only trace amounts of $\mathbf{3 a}$ ' and 3a". Unfortunately, the addition of $4 \AA$ molecular sieves did not improve the yield (Table 1, entry 10). Gratifyingly, decreasing the manganese catalyst and base loading to $1 \mathrm{~mol} \%$ afforded the desired product 3a in $77 \%$ yield (Table 1, entry 11). Use of manganese pentacarbonyl bromide or the base only did not afford any product, indicating the crucial role of the metal catalyst (Table 1, entries 12-13).

Scheme 3. Scope of Different Symmetrical and Unsymmetrical Diols. $^{a}$

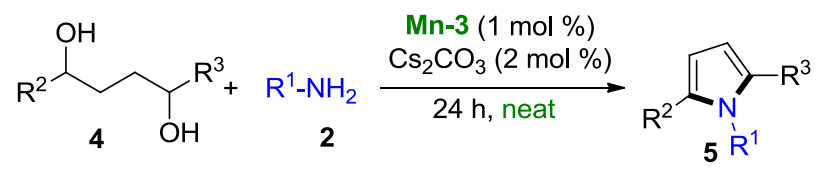

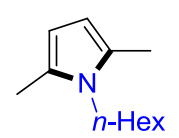

5a, $94 \%$<smiles>Cc1ccc(C)n1CCc1ccccc1</smiles>

5d, $73 \%$

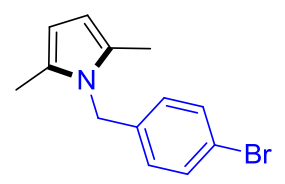

5g, $80 \%$

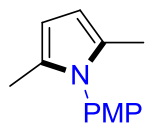

5j, 33\%

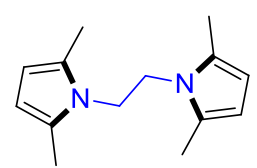

$5 \mathrm{~m}, 73 \%{ }^{c}$

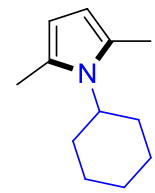

5b, $67 \%$

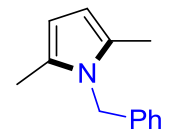

5e, $96 \%$

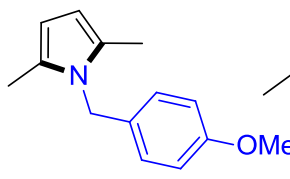

5h, $83 \%$<smiles>[X][Te]n1c(-c2ccccc2)ccc1-c1ccccc1</smiles>

5k, $45 \%^{b}$

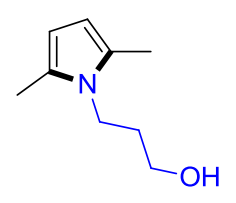

5c, $47 \%$

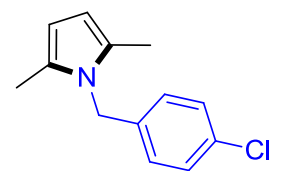

5f, $79 \%$

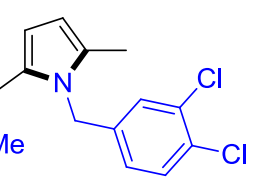

$5 i, 58 \%$<smiles>c1ccc(Cn2cccc2-c2ccccc2)cc1</smiles>

5I, $47 \%^{b}$

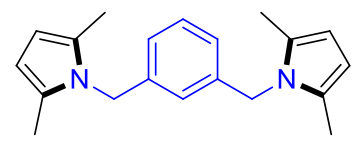

5n, $77 \%^{c}$

${ }^{a}$ Reaction conditions: 4 (0.5 mmol), 2 (1.0 mmol), Mn-3 (0.005 mmol $), \mathrm{Cs}_{2} \mathrm{CO}_{3}(0.01 \mathrm{mmol})$ at $150{ }^{\circ} \mathrm{C}$ for $24 \mathrm{~h} .{ }^{b} \mathbf{M n}-3(0.01$ $\mathrm{mmol}), \mathrm{Cs}_{2} \mathrm{CO}_{3}(0.025 \mathrm{mmol})$. ${ }^{c}$ diamine $(0.5 \mathrm{mmol})$, diol $(1.5$ mmol).

In order to demonstrate the general applicability of the reaction, a variety of primary amines were reacted with 1,4butanediol (1) as a coupling partner (Scheme 2). Long-chain primary amines reacted smoothly with $\mathbf{1}$, leading to the pyrroles $\mathbf{3 a}$ and $\mathbf{3 b}$ in good yield. When cyclohexyl amine was used as a substrate, the desired product $3 \mathbf{c}$ was obtained in $68 \%$ yield. Slightly better yield was obtained when phenylethylamine was used and the corresponding pyrrole $\mathbf{3 d}$ was obtained in very good yield. Likewise, the reaction could

also be applied successfully to medicinally relevant tryptamine affording the pyrrole $\mathbf{3 e}$ in $78 \%$ yield. Furthermore, benzylamines bearing electron-withdrawing and electrondonating groups were successfully reacted and provided the corresponding pyrroles $\mathbf{3 f - 3 i}$ in moderate to good yields. Interestingly, amines bearing heterocycles such as pyridine and furane could also be used as coupling partners providing the desired pyrroles $\mathbf{3} \mathbf{j}$ and $\mathbf{3 k}$ in moderate to good yields. In addition, $\alpha$-substituted amines such as $\alpha$-methylbenzylamine and benzhydrylamine were successfully applied and afforded the pyrroles $\mathbf{3} \mathbf{I}$ and $\mathbf{3 m}$ in moderate to good yields. Utilizing aromatic amines such as para-methoxy aniline appeared to be more challenging due to the lower nucleophilicity and only $42 \%$ of the desired product $3 \mathbf{n}$ could be isolated. Next, we successfully extended the scope by accessing symmetrical bispyrrole 30 from the corresponding diamine.

Encouraged by these results, we decided to further expand the scope and to use secondary diols, such as 2,5-hexanediol (4a) as a coupling partner (Scheme 3$).^{8}$ In analogy to Scheme 2, different $\alpha$-branched and unbranched primary amines and aniline derivatives are tolerated and the desired substituted pyrroles 5a-5i were obtained in good to excellent yields. In order to further prove the generality of the presented catalytic system, mono- and diphenylbutanediol were investigated and readily converted to the corresponding pyrroles $\mathbf{5 k}$ and $\mathbf{5 l}$ in moderate yields. Finally, further extension led to the synthesis of the symmetrical bis-pyrroles $\mathbf{5 m}$ and $\mathbf{5 n}$ in good yields. To demonstrate the practicability of this newly developed methodology, we conducted a gram scale synthesis of the tryptamine substituted pyrrole 7 and the desired product was isolated in excellent yield without the need of chromatography purification (Scheme 4).

Scheme 4: Gram Scale Synthesis of Tryptaminesubstituted Pyrrole 7.

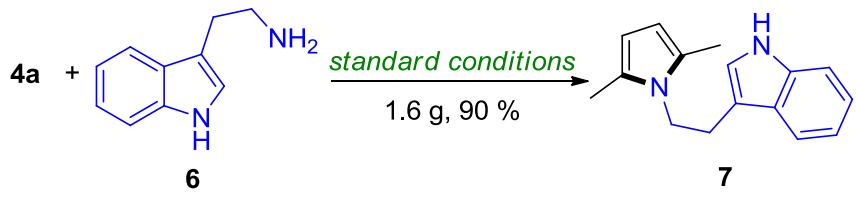

In summary, we report a general and selective synthesis of $\mathrm{N}$ substituted pyrroles from low-cost renewable diols and primary amines. The reaction is catalyzed by a well-defined, benchstable, homogeneous base metal catalyst which circumvents the use of stoichiometric amounts of mutagenic reagents and produces water and hydrogen gas as the sole by-products. The high potential of this catalytic system was demonstrated by the synthesis of a wide variety of pyrroles in good to excellent yields.

\section{ASSOCIATED CONTENT}

\section{Supporting Information}

The Supporting Information is available free of charge on the ACS Publications website: Experimental data (PDF)

\section{AUTHORS INFORMATION}

\section{Corresponding Authors}

* Magnus.Rueping@ rwth-aachen.de

* Osama.Elsepelgy@rwth-aachen.de 


\section{Notes}

The authors declare no competing financial interests.

\section{ACKNOWLEDGMENTS}

J.C.B. is thankful for financial support of the German Federal Environmental Foundation (DBU).

\section{REFERENCES}

(1) (a) Biomass and Biofuels (Eds.: S. Jose and T. Bhaskar), CRC Press, 2015. (b) Vispute, T. P.; Zhang, H.; Sanna, A.; Xiao, R.; Huber, G. W. Science 2010, 330, 1222-1227.

(2) Selected reviews: (a) Corma, A.; Navas, J.; Sabater, M. J. Chem. Rev. 2018, 118, 1410-1459. (b) Chelucci, G. Coord. Chem. Rev. 2017, 331, 1-36. (c) Huang, F.; Liu, Z.; Yu, Z. Angew. Chem. Int. Ed. 2016, 55, 862-875. (d) Nandakumar, A.; Midya, S. P.; Landge, V. G.; Balaraman, E. Angew. Chem. Int. Ed. 2015, 54, 11022-11034. (e) Yang, Q.; Wang, Q.; Yu, Z. Chem. Soc. Rev. 2015, 44, 2305-2329. (f) Leonard, J.; Blacker, A. J.; Marsden, S. P.; Jones, M. F.; Mulholland, K. R.; Newton, R. A. Org. Process Res. Dev. 2015, 19, 1400-1410. (g) Gunanathan, C.; Milstein, D. Science 2013, 341, 1229712. (h) Obora, Y. ACS Catal. 2014, 4, 3972-3981. (i) Guillena, G.; Ramón, D. J.; Yus, M. Chem. Rev. 2010, 110, 16111641. (j) Dobereiner, G. E.; Crabtree, R. H. Chem. Rev. 2010, 110, 681-703. (k) Hamid, M. H. S. A.; Slatford, P. A.; Williams, J. M. J. Adv. Synth. Catal. 2007, 349, 1555-1575.

(3) (a) Heterocyclic Chemistry, 5th ed. (Eds.: J. A. Joule, K. Mills) Wiley, UK, 2010. (b) Chemistry of Heterocyclic Compounds: Pyrroles, Part 1 and 2: Volume 48 Editor(s): Jones R. A., 2008. (c) Setsune, J.-I. Chem. Rev. 2017, 117, 3044-3101. (d) MacDiarmid, A. G. Angew. Chem. Int. Ed. 2001, 40, 2581-2590. (e) Vernitskaya, T. V.; Efimov, O. N. Russ. Chem. Rev. 1997, 66, 443-457.

(4) (a) Paal, C. Ber. Dtsch. Chem. Ges. 1885, 18, 367-371. (b) Knorr, L. Ber. Dtsch. Chem. Ges. 1884, 17, 1635-1642. (c) Hantzsch, A. Ber. Dtsch. Chem. Ges. 1890, 23, 1474-1476.

(5) (a) Clauson-Kaas, N. Acta Chem. Scand. 1952, 6, 667-670. (b) Guida, W. C.; Mathre, D. J. J. Org. Chem., 1980, 45, 3172-3176.

(6) (a) Yasushi, T.; Yasuharu, Y.; Keun-Tae, H.; Yoshihisa, W. Bull. Chem. Soc. Jpn, 1987, 60, 3456-3458. (b) Yan, T.; Barta, K. ChemSusChem. 2016, 9, 2321-2325. (c) Emayavaramban, B.; Sen, M.; Sundararaju, B. Org. Lett. 2017, 19, 6-9.

(7) Scalacci, N.; Black, G. W.; Mattedi, G.; Brown, N. L.; Turner, N. J.; Castagnolo, D. ACS Catal. 2017, 7, 1295-1300.

(8) (a) Schley, N. D.; Dobereiner, G. E.; Crabtree, R. H. Organometallics 2011, 30, 4174-4179. (b) Daw, P.; Chakraborty, S.; Garg, J. A.; Ben-David, Y.; Milstein, D. Angew. Chem. Int. Ed. 2016, $55,14373-14377$.

(9) (a) Fujita, K.-i.; Fujii, T.; Yamaguchi, R. Org. Lett. 2004, 6, 3525-3528. (b) Hamid, M. Haniti S. A.; Allen, C. L.; Lamb, G. W.; Maxwell, A. C.; Maytum, H. C.; Watson A. J. A.; Williams, J. M. J. J. Am. Chem. Soc. 2009, 131, 1766-1774. (c) Yan, T.; Feringa, B. L.; Barta, K. Nature Commun. 2014, 5, 5602.

(10) (a) Zhang, J.; Senthilkumar, M.; Ghosh S. C.; Hong, S. H. Angew. Chem. Int. Ed., 2010, 49, 6391-6395. (b) Espinosa-Jalapa, N. A.; Kumar A.; Milstein, D. J. Am. Chem. Soc. 2017, 139, 11722 11725 .

(11) (a) Zhao J.; Hartwig, J. F. Organometallics 2005, 24, 2441-2446. (b) Nguyen, D. H.; Trivelli, X.; Capet, F.; Paul, J.-F.; Dumeignil, F.; Gauvin, R. M. ACS Catalysis 2017, 7, 2022-2032.

(12) For pyrrole synthesis from amino alcohols and secondary alcohols (a) Michlik, S.; Kempe, R. A. Nat. Chem. 2013, 5, $140-$ 144. (b) Srimani, D.; Ben-David, Y.; Milstein, D. Angew. Chem. Int. Ed. 2013, 52, 4012 - 4015. (c) Lida, k.; Miura, T.; Anda, J.; Saito, S. Org. Lett. 2013, 15, 1436-1439. (d) Kallmeier, F.; Dudziec, B., Irrgang, T., Kempe R. Angew. Chem. Int. Ed. 2017, 56, 7261 - 7265. For three component synthesis of pyrrole: (e) Zhang, M.; Neumann, H.; Beller, M. Angew. Chem. Int. Ed. 2013, 52, 597 - 601. (f) Zhang, M.; Fang, X. J.; Neumann, H.; Beller, M. J. Am. Chem. Soc. 2013 135, 11384 - 11388. (g) Dang, T.T.; Seayad, A. M. Chem Asain J. 2017, 12, 2383- 2387.
(13) Selected reviews: (a) Filonenko, G.A.; van Putten, R.; Hensen, E.J.M.; Pidko, E.A. Chem. Soc. Rev. 2018, 47, 1459-1483. (b) Zell, T.; Langer, R. ChemCatChem 2018, 10, 1930-1940. (c) Kallmeier, F.; Kempe, R. Angew. Chem. Int. Ed. 2018, 57, 46-60. (d) Maji, B.; Barman, M. K. Synthesis 2017, 49, 3377-3393. (e) Liu, W.; Ackermann, L. ACS Catal. 2016, 6, 3743-3752. (f) Valyaev, D. A.; Lavigne, G.; Lugan, N. Coord. Chem. Rev. 2016, 308, 191-235.

(14) For general reviews on base metal catalysis: (a) Chirik, P.; Morris, R. Acc. Chem. Res. 2015, 48, 2495-2495. (b) Bauer, I.; Knölker, H.-J. Chem. Rev. 2015, 115, 3170-3387. (c) Morris, R. H. Acc. Chem. Res. 2015, 48, 1494-1502. (d) Bullock, R. M., Catalysis without Precious Metals. Wiley-VCH: Weinheim, 2010. (e) Plietker B., Iron Catalysis in Organic Chemistry: Reactions and applications, 2nd ed., Wiley-VCH, Weinheim, 2008.

(15) Selected examples: (a) Elangovan, S.; Topf, C.; Fischer, S.; Jiao, H.; Spannenberg, A.; Baumann, W.; Ludwig, R.; Junge, K.; Beller, M. J. Am. Chem. Soc. 2016, 138, 8809-8814. (b) Kallmeier, F.; Irrgang, T.; Dietel, T.; Kempe, R. Angew. Chem., Int. Ed. 2016, 55, 11806-11809. (c) Widegren, M. B.; Harkness, G. J.; Slawin, A. M. Z.; Cordes, D. B.; Clarke, M. L.; A. Angew. Chem. Int. Ed. 2017, 56, 5825-5828. (d) Bruneau-Voisine, A.; Wang, D.; Dorcet, V.; Roisnel, T.; Darcel, C.; Sortais, J. B. Org. Lett. 2017, 19, 3656-3659. (e) Perez, M.; Elangovan, S.; Spannenberg, A.; Junge, K.; Beller, M. ChemSusChem 2017, 10, 83-86. (f) Zirakzadeh, A.; de Aguiar, S. R. M. M.; Stöger, B.; Widhalm, M.; Kirchner, K. ChemCatChem 2017, 9, 1744-1748. (g) Glatz, M.; Stöger, B.; Himmelbauer, D.; Veiros, L. F.; Kirchner, K. ACS Catal. 2018, 8, 4009-4016. (h) Brzozowska, A.; Azofra, L. M.; Zubar, V.; Atodiresei, I.; Cavallo, L.; Rueping, M.; ElSepelgy, O.; ACS Catal. 2018, 8, 4103-4109. (i) Zubar, V.; Lebedev, Y.; Azofra, L. M.; Cavallo, L.; El-Sepelgy, O.; Rueping, M. Angew. Chem. Int. Ed. 2018, 57, 13439-13443. (j) Zhou, Y. P.; Mo, Z.; Luecke, M. P.; Driess, M., Chem. Eur. J. 2018, 24, 4780-4784.

(16) (a) Mukherjee, A.; Nerush, A.; Leitus, G.; Shimon, L. J. W.; Ben-David, Y.; Espinosa Jalapa, N. A.; Milstein, D. J. Am. Chem. Soc. 2016, 138, 4298-4301. (b) Mastalir, M.; Glatz, M.; Pittenauer, E.; Allmaier, G.; Kirchner, K. J. Am. Chem. Soc. 2016, 138, 1554315546. (c) Deibl, N.; Kempe, R. Angew. Chem., Int. Ed. 2017, 56, 1663-1666. (d) Daw, P.; Kumar, A.; Espinosa-Jalapa, N. A.; DiskinPosner, Y.; Ben-David, Y.; Milstein. D. ACS Catal. 2018, 8, 77347731. (g) Das, K.; Mondal, A.; Srimani, D. J. Org. Chem., 2018, 83, 9553-9560. (h) Das, K.; Mondal, A.; Srimani, D., Chem. Commun., 2018, 54, 10582-10585.

(17) Selected examples: (a) Elangovan, S.; Neumann, J.; Sortais, J.-B.; Junge, K.; Darcel, C.; Beller, M. Nat. Commun. 2016, 7, 12641. (b) Pena-Lopez, M.; Piehl, P.; Elangovan, S.; Neumann, H.; Beller, M. Angew. Chem. Int. Ed. 2016, 55, 14967-14971. (c) Fu, S.; Shao, Z.; Wang, Y.; Liu, Q. J. Am. Chem. Soc. 2017, 139, 1194111948. (d) Bruneau-Voisine, A.; Wang, D.; Dorcet, V.; Roisnel, T.; Darcel, C.; Sortais, J.-B. J. Catal. 2017, 347, 57-62. (e) Mastalir, M.; Pittenauer, E.; Allmaier, G.; Kirchner, K. J. Am. Chem. Soc. 2017, 139, 8812-8815. (f) Fertig, R.; Irrgang, T.; Freitag, F.; Zander, J.; Kempe, R. ACS Catal. 2018, 8, 8525-8530. (g) El-Sepelgy, O.; Matador, E.; Brzozowska, A.; Rueping, M. ChemSusChem, 2018, DOI:10.1002/CSSC.201801660. (h) Liu, T.; Wang, L.; Wu, K.; Yu, Z. ACS Catal. 2018, 8, 7201-7207. (i) Kulkarni; N. V.; Brennessel; W. W.; Jones; W. D. ACS Catal. 2018, 8, 997-1002. (j) Jana, A.; Reddy, C. B.; Maji, B. ACS Catal. 2018, 8, 9226-9231. (k) Sklyaruk, J.; Borghs, J. C.; El-Sepelgy, O.; Rueping, M. Angew. Chem., Int. Ed. 2018, DOI: 10.1002/anie.201810885. (1) Jang, Y. K.; Krückel, T.; Rueping, El-Sepelgy, O. Org. Lett. 2018, DOI: 10.1021/acs.orglett.8b03184.

(18) (a) El-Sepelgy, O.; Alandini, N.; Rueping, M. Angew. Chem. Int. Ed. 2016, 55, 13602-13605. (b) El-Sepelgy, O.; Brzozowska, A.; Rueping, M. ChemSusChem 2017, 10, 1664-1668. (c) El-Sepelgy, O.; Brzozowska, A.; Azofra, L. M.; Jang, Y. K.; Cavallo, L.; Rueping, M. Angew. Chem. Int. Ed. 2017, 56, 1486314867. (d) El-Sepelgy, O.; Brzozowska, A.; Sklyaruk, J.; Jang, Y. K.; Zubar, V.; Rueping, M.; Org. Lett. 2018, 20, 696-679.

(19) For reviews catalysis: (a) Khusnutdinova, R.; Milstein, D. Angew. Chem. Int. Ed. 2015, 54, 12236-12273. (b) Lyaskovskyy, V.; de Bruin, B. ACS Catal. 2012, 2, 270-279. 


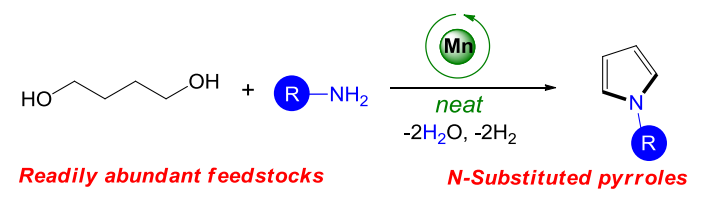

- First row metal catalyst - Catalytic amount of $\mathrm{K}_{2} \mathrm{CO}_{3}$

- Unprecedented selectivity 